\title{
STRATEGI HIDUP MASYARAKAT PETANI DI KELURAHAN PANDU, KECAMATAN BUNAKEN, KOTA MANADO
}

\author{
Reno Raven Derek \\ Elsje P. Manginsela \\ Benu Olfie L.S.
}

\begin{abstract}
This study aims to describe how farmers carry out a strategy of life on three groups of farmer: upper layer, middle layer and peasant farmers to finance their family daily life. This research was conducted in the urban village of Pandu, Sub-District Bunaken, Manado City. Most of them live from farming activities. The research was conducted in November 2015 through to March 2016. The primary data obtained from interviews to three (3) groups. Selection of the sample is purposive stratified sampling. Each group selected five respondents, so a total of 15 respondents. Collection of secondary data derived from the Urban Village Office of Pandu, Manado City. The results showed that the upper and middle groups of farmers tend to apply the accumulation strategy while consolidation strategy was not found. The two groups have incomes that exceed the needs of farming and of the results they could buy a cow, land or other assets. While farmers lower group implement survival strategies. This farmersgroup use their earnings for the daily needs of the family and the other half to farm. Limited income makes farmers can not save even they have to borrow money to supplement the family income either eat or buy school supplies for children.
\end{abstract}

Keywords : accumulation strategy, consolidation strategy, survival strategy, urban village of Pandu, Manado City

\begin{abstract}
ABSTRAK
Penelitian ini bertujuan untuk mendeskripsikan bagaimana cara petani melakukan strategi hidup baik petani lapisan atas, petani lapisan menengah dan petani lapisan bawah untuk membiayai kehidupan keluarganya sehari-hari. Penelitian ini dilakukan di Kelurahan Pandu, Kecamatan Bunaken, Kota Manado yang sebagian masyarakatnya hidup dari kegiatan pertanian. Penelitian dilaksanakan pada Bulan November 2015 sampai dengan Maret 2016. Data primer diperoleh dari wawancara langsung kepada 3 (tiga) kelompok. Pemilihan sampel dengan metode stratifikasi secara sengaja (stratified purposive sampling). Setiap kelompok dipilih 5 responden sehingga total 15 responden. Pengumpulan data sekunder berasal dari Kantor Kelurahan Pandu, Kota Manado. Hasil penelitian menunjukan bahwa petani lapisan atas dan petani lapisan menengah cenderung menerapkan strategi akumulasi sedangkan strategi konsolidasi tidak ditemukan. Kedua lapisan tersebut memiliki pendapatan yang melebihi kebutuhan untuk bertani dan dari hasil tersebut mereka bisa membelikan Sapi, tanah atau aset lainnya. Sedangkan petani lapisan bawah menerapkan strategi bertahan hidup. Petani lapisan ini menggunakan pendapatan mereka untuk kebutuhan keseharian keluarga dan setengahnya lagi untuk bertani. Keterbatasan pendapatan membuat petani tidak dapat menabung bahkan mereka harus meminjam uang untuk menambah pendapatan keluarga baik makan ataupun membeli perlengkapan sekolah untuk anak-anak.
\end{abstract}

Kata Kunci : strategi akumulasi, strategi konsolidasi, strategi bertahan hidup, Kelurahan Pandu, Kota Manado 


\section{PENDAHULUAN}

\section{Latar Belakang}

Indonesia dikenal sebagai negara agraris karena sebagian besar penduduknya bermata pencaharian di bidang pertanian. Negara ini diuntungkan karena dikaruniai kondisi alam yang mendukung, hamparan lahan yang luas, keragaman hayati yang melimpah, serta beriklim tropis dimana sinar matahari terjadi sepanjang tahun sehingga bisa menanam sepanjang tahun. Realita sumberdaya alam seperti ini sewajarnya mampu membangkitkan Indonesia menjadi negara yang makmur, tercukupi kebutuhan pangan seluruh warganya. Meskipun belum optimal, pertanian menjadi salah satu sektor riil yang memiliki peran sangat nyata dalam membantu penghasilan devisa negara (Warsani, 2013).

Seperti yang dikemukakan Arini dalam Kumesan, dkk (2015) bahwa teori strategi hidup rumah tangga (household strategy of life) mengacu pada pola-pola yang dibentuk oleh berbagai usaha yang digunakan manusia untuk memenuhi persyaratan hidup yang dibutuhkannya dan untuk memecahkan masalah yang mereka hadapi. Berdasarkan teori ini maka petani akan memanfaatkan sumberdaya yang tersedia sesuai dengan situasi yang dihadapi.

Menurut Atmadja (2006) sebagian besar petani hidup dalam ketertinggalan dengan kondisi kehidupan yang perlu ditingkatkan. Dimasyarakat profesi sebagai petani biasanya digunakan sebagai perlindungan dari status pengangguran sehingga banyak masyarakat yang dikategorikan sebagai petani.

Kebanyakan masyarakat Indonesia, terutama yang hidup di desa dan di pedalaman, untuk menghidupi keluarganya masih bersifat tradisional seperti praktek usaha tani, kebiasaan makan, cara memasak, cara membuat rumah, cara membuat alat-alat rumah tangga dan hiburan bagi masyarakat,dimana semua hal tersebut itu cenderung menjadi adat kebiasaan yang diturunkan dari generasi ke generasi berikutnya (Lutfia, 2015 ).
Pekerjaan sebagai petani merupakan salah satu alternatif untuk bisa mempertahankan kehidupan di desa, dimana pekerjaan ini dilakukan dengan tidak memerlukan pengetahuan yang tinggi tetapi mengandalkan tenaga. Bagi sebagian masyarakat tani yang miskin walaupun terasa berat beban untuk mencukupi bermacammacam kebutuhan hidup, dengan pekerjaanyang sederhana ini mereka dapat menyekolahkan anak dengan upah yang tak seberapa diatur sehingga dapat mencukupkan kebutuhan makan, minum dan pakaian (Khairani, 2010).

Bagi petani miskin, menekuni pekerjaan dengan upah yang pas-pasan membuat mereka harus pandai untuk memenuhi kebutuhan hidupnya. Setiap anggota masyarakat petani selalu menginginkan peningkatan tingkat kesejahteraan didalam kehidupannya. White, dkk (1990) mencatat bahwa rumahtangga lapisan atas adalah petani yang mengusahakan tanah pertanian luas, yang menguasai surplus produk pertanian melebihi kebutuhan hidup mereka.

Dalam dunia pertanian manusia dan tanah merupakan dua kalimat yang tak asing lagi didengar, karena tanah merupakan tempat berpijak manusia dan tempat manusia untuk mengolah tanaman pertaniannya demi kelangsungan hidup (Mardikantoro, 2013).

Proses adaptasi merupakan salah satu bagian dari proses evolusi kebudayaan, yakni proses yang mencakup rangkaian usaha-usaha manusia untuk menyesuaikan diri atau memberi respon terhadap perubahan lingkungan fisik maupun sosial yang terjadi secara temporal. Perubahan lingkungan yang sangat berpengaruh terhadap adaptasi manusia adalah perubahan lingkungan yang berupa bencana, yaitu kejadian yang menjadi ancaman terhadap kelangsungan hidup organisme termasuk disini adalah manusia (Sugihardjo, dkk, 2012).

Popkin dalam Sugihardjo, dkk (2012) berasumsi bahwa kehidupan ekonomi petani sangat dipengaruhi oleh keputusan individual dalam menghadapi tantangan. Melalui analisis individual akan dapat dibuat generalisasi 
tentang pandangan petani terhadap ekonomi pasar, keberanian berspekulasi, menghadapi resiko, hubungan patron-klien, konflik yang terjadi.

Bambang dan Famiola dalam Sugihardjo, dkk (2012) mengemukakan ada empat bentuk kekuatan hubungan yang dapat dilihat dari suatu jaringan sosial:

1. Intensity, kekuatan hubungan dapat diukur dari derajat atau frekuensi kontak individu dalam komunitas tersebut pada waktu tertentu;

2. Resiprocity, derajat individu-individu dalam komunitas tersebut untuk melakukan pertukaran secara timbal balik;

3. Kejelasan terhadap pengharapan dari hubungan yang terjalin antar individu dalam komunitas yang diamati;

4. Multiplexity, derajat jenis banyak peran yang dilakoni oleh individu dalam komunitas atau pranata.

Hubungan antara aset dan strategi yang diterapkan memiliki hubungan positif dan negatif. Kepemilikan lahan, pendidikan, penghasilan yang diterima, kepemilikan aset motor, kepemilikan ternak memiliki hubungan positif dengan strategi penghidupan yang dilakukan. Artinya semakin banyak aset yang dimiliki rumah tangga maka strategi yang diterapkan semakin meningkatkan strateginya untuk keluar dari strategi bertahan hidup.

Hubungan lain juga ditunjukkan dilihat dari kualitas pemukiman dengan strategi penghidupan yang memiliki hubungan positif. Luas lahan merupakan indikator untuk melihat hubungan dengan strategi penghidupan. Sedangkan variabel umur dan jumlah anak memiliki hubungan signifikan tetapi bersifat negatif (Arif, 2011).

Demikian halnya petani yang ada di Kelurahan Pandu yaitu petani lapisan atas, petani lapisan menengah dan petani lapisan bawah. Mereka bekerja bukan hanya sebagai petani tetapi ada pekerjaan non-pertanian lainnya untuk memenuhi kebutuhan hidup keluarganya. Misalkan Pegawai Negri, buruh bangunan, tukang ojek, sopir, buruh peternakan ayam dan lain-lain.

Manusia pada dasarnya senantiasa menginginkan kebutuhannya terpenuhi. Cara pemenuhan kebutuhan tidak lepas dengan berbagai norma yang berlaku dalam masyarakat. Norma-norma tersebut untuk menghindari pertentangan dan ketegangan antar individu dan individu, individu dan kelompok maupun kelompok dengan kelompok (Sumarnonugroho, 1991).

Manusia sebagai mahluk yang berfikir juga sebagai mahluk sosial yang memiliki rasa, cipta dan karsa. Hati atau batin manusia mengalami keadaan senang, tentram, sedih, pilu, kecewa dan marah. Kesanggupan batin mengadakan sesuatu hal sedangkan karsa adalah berkehendak, kemauan, keinginan, atau harapan-harapan yang kokoh (Sumarnonugroho, 1991).

Manusia mengalami keadaan senang, tentram, sedih, pilu, kecewa, dan marah. Tetapi manusia juga tidak lepas dari normanorma yang berlaku, baik individu dan individu, individu dan kelompok maupun kelompok dengan kelompok (Breman dalam Lubis, 1999).

Perry dalam Ying (2013) membagi strategi kelangsungan hidup bagi petani Cina Utara menjadi dua kategori: strategi predator dengan tujuan mengambil kekayaan orang lain dan strategi defensif untuk mencegah orang luar mengambil. Klasifikasi ini dapat digunakan untuk membedakan antara bentuk semangat dalam politik perdebatan dan kehidupan sehari-hari. Meskipun logika untuk membangun kebajikan melalui kekuatan dalam keseharian kadang-kadang dapat menjadi lebih agresif.

\section{Masyarakat Petani}

Masyarakat merupakan kelompok manusia yang telah hidup dalam kurun waktu tertentu yang bekerjasama sehingga mereka itu dapat mengorganisasikan dirinya dan berpikir tentang dirinya sebagai satu kesatuan sosial dan batas-batas tertentu (Harsojo, 1974).

Menurut Samsudin (1982), petani adalah mereka yang untuk sementara waktu (temporary) atau secara tetap (permanent) menguasai sebidang tanah pertanian, menguasai sesuatu cabang atau beberapa cabang usaha tani dan mengerjakan sendiri, baik dengan tenaga sendiri maupun tenaga 
bayaran. Menguasai sebidang tanah dapat diartikan pula menyewa, bagi hasil atau berupa memiliki tanah sendiri. Di samping menggunakan tenaga sendiri ia dapat menggunakan tenaga kerja yang bersifat tidak tetap.

\section{Kebutuhan Hidup Manusia}

Berapa asumsi fundamental teori yang berkaitan dengan kebutuhan hidup manusia dikemukakan oleh (Ritzer, 2004) sebagai berikut:

1. Tindakan manusia muncul dari kesadarannya sendiri sebagai subjek dan dari situasi eksternal dalam posisinya sebagai objek.

2. Sebagai subjek, manusia bertindak atau berperilaku untuk mencapai tujuan-tujuan tertentu. Jadi tindakan manusia bukan tanpa tujuan.

3. Dalam bertindak, manusia menggunakan cara, teknik, prosedur, metode serta perangkat yang diperkirakan cocok untuk mencapai tujuan tersebut.

4. Kelangsungan tindakan manusia hanya dibatasi oleh kondisi yang tidak dapat diubah dengan sendirinya.

5. Manusia memilih, menilai dan mengevaluasi terhadap tindakan-tindakan yang akan, sedang dan yang telah dilakukan.

6. Ukuran-ukuran atau aturan-aturan dan prisip-prinsip moral diharapkan timbul pada saat pengambilan keputusan.

7. Studi mengenai antar hubungan sosial memerlukan pemakaian teknik penemuan yang bersifat subyektif seperti metode verstehen, imajinasi, sympatetic reconstruction atau seakan-akan mengalami sendiri (vicarious experience).

Menurut Arif, 2011 dan Nugroho, dkk (1991) kebutuhan manusia dapat dilihat dari beberapa komponen, yaitu:

1. Kebutuhan kasih sayang

2. Kebutuhan untuk hidup

3. Kebutuhan akan merasa aman

4. Kebutuhan untuk mencapai sesuatu

5. Kebutuhan untuk bertingkah laku sosial
6. Kebutuhan agar diterima dalam kelompok.

7. Melakukan pekerjaan yang disenangi

\section{Strategi Hidup Masyarakat}

Pada hakekatnya strategi berarti hal yang berkaitan dengan cara dan usaha masyarakat, atau suatu bangsa mencapai tujuannya (Moertopo, 1974). Selanjutnya, Tjokroamidjoyo dan Mustopadidjaya dalam Jannah dan Kadarisman (2015), memaknai strategi sebagai "perhitungan" mengenai rangkaian kebijaksanaan dan langkah-langkah pelaksanaan namun Wahyudi (1996) mengatakan bahwa strategi adalah mengerjakan sesuatu yang tepat. Jadi strategi hidup masyarakat adalah rangkaian kebijaksanaan untuk mengerjakan sesuatu yang tepat demi mencapai tujuan.

Terdapat dua pemikiran yang berbeda menyangkut istilah survival (strategi hidup masyarakat). Menurut Sajogyo (1985), Mosher berbicara tentang survival yang dilakukan oleh petani lapisan atas dan menengah (farmers) sedangkan Scott (1990) membahas menyangkut petani lapisan bawah/miskin (peasants). Menurut Mosher (1998) survival sebagai kemampuan segenap anggota keluarga dalam mengelola berbagai aset yang dimilikinya. Berdasarkan konsep ini Mosher telah membuat kerangka analisis yang meliputi berbagai pengelolaan aset diantaranya yakni:

1. Aset Tenaga Kerja (labour assets), misalnya meningkatkan keterlibatan wanita dan anakanak dalam keluarga untuk bekerja membantu ekonomi dalam rumah tangga (Tenaga Kerja dalam Keluarga - TKDK dan Tenaga Kerja Luar Keluarga - TKLK).

2. Aset Modal Manusia (human capital assets), misalnya memanfaatkan status kesehatan yang dapat menentukan kapasitas orang untuk bekerja atau ketrampilan, dan pendidikan yang menentukan kembalian atau hasil kerja (return) terhadap tenaga yang dikeluarkannya.

3. Aset Produktif (productive assets), misalnya menggunakan rumah, sawah, ternak, tanaman untuk keperluan hidupnya.

4. Aset Relasi Rumah Tangga atau keluarga besar, kelompok etnis, migrasi tenaga kerja 
dan mekanisme "uang kiriman" (remittances).

5. Aset Modal Sosial (social capital assets), misalnya memanfaatkan lembaga-lembaga sosial lokal dan pemberian kredit informal dalam proses dan sistem perekonomian keluarga.

Berbeda dengan Mosher, Scott, 1990 menjelaskan mekanisme survival sebagai upaya yang dilakukan kelompok miskin guna mempertahankan hidupnya. Upaya tersebut diantaranya yakni mereka dapat mengikat sabuk lebih kencang dengan mengurangi frekuensi makan yang mutunya lebih rendah. Di samping itu menggunakan alternatif subsisten lainnya dengan melakukan "swadaya" yang mencakup kegiatan-kegiatan seperti berjualan kecilkecilan, bekerja sebagai tukang, buruh lepas atau bermigrasi serta upaya terakhir menggunakan jaringan-jaringan sosial yang berfungsi sebagai pengetahuan kepada petani selama masa krisis ekonomi untuk lebih kreatif lagi melangsungkan kehidupan keluarga.

Menurut Partini dkk dalam Juwanita (2004), strategi sering dilakukan untuk menyiasati kekurangan dalam memenuhi kebutuhan hidup, terutama dalam keadaan mendesak atau mendadak. Berbagai strategi dilakukan dengan meminjam uang, menjual barang-barang simpanan seperti perhiasan ataupun menggadaikan barang. Strategi cenderung dilakukan pada saat kebutuhan mendadak, antara lain dalam keadaan sakit, membayar sewa rumah dan kekurangan dalam kebutuhan hidup sehari-hari.

Breman (1980; Lubis, 1999) menemu-kan bahwa strategi hidup pada masyarakat petani dipengaruhi oleh kelas sosial. Tiga lapisan masyarakat mempunyai strategi hidupnya masing-masing.

1. Lapisan atas menerapkan Strategi Akumulasi, yaitu petani mengumpulkan harta mereka sehingga semakin hari semakin bertambah baik dalam tanah pertanian ataupun usaha di luar bertani. Contoh uang yang di dapatkan dalam hasil pertanian di tabung, agar semakin hari uang yang di tabung semakin meningkat atau semakin hari semakin banyak.

2. Lapisan menengah melakukan Strategi Konsolidasi, yaitu petani yang mempunyai lahan yang berjauhan lokasi. Salah satu lahan dijual untuk membeli lahan yang berdekatan lokasinya sehingga menjadi satu hamparan yang lebih luas agar lebih mudah di jangkau dan dikelola.

3. Lapisan bawah menempuh cara bertahan hidup, bagi masyarakat kelas bawah yang lebih berkonsentrasi untuk memenuhi kebutuhan hariannya, membuat mereka cenderung berorientasi pada jangka pendek dan ketahanan fisik. Contoh mereka hanya berpikir mendapatkan uang untuk membeli makan dalam satu hari, karena mereka tidak mempunyai uang untuk membeli lebih banyak dalam melangsungkan kehidupan keluarga mereka.

\section{Perumusan Masalah}

Berdasarkan latar belakang maka perumusan masalah pada penelitian ini adalah bagaimana cara mereka melakukan strategi hidup untuk melangsungkan kehidupan keluarga baik petani lapisan atas, petani lapisan menengah dan petani lapisan bawah.

\section{Tujuan dan Manfaat Penelitian}

Berdasarkan masalah yang telah dikemukakan maka tujuan penelitian ini, yaitu mendeskripsikan bagaimana cara petani melakukan strategi hidup masyarakat baik petani lapisan atas, petani lapisan menengah dan petani lapisan bawah untuk membiayai kehidupan keluarganya seharihari. Baik bekerja sebagai petani maupun pekerjaan tambahan di luar pekerjaan sebagai petani. Memberikan manfaat informasi yang berguna kepada petanipetani dalam strategi hidup masyarakat petani. 


\section{METODOLOGI PENELITIAN}

\section{Tempat dan Waktu Penelitian}

Penelitian ini dilakukan di, Kelurahan

Pandu Kecamatan Bunaken Kota Manado yang sebagian masyarakatnya hidup dari kegiatan pertanian. Penelitian dilaksanakan pada Bulan November 2015 sampai dengan Maret 2016.

\section{Metode Pengumpulan Data}

Data yang digunakan dalam penelitian ini adalah data primer dan data sekunder. Data primer diperoleh dari wawancara langsung kepada 3 (tiga) kelompok secara sengaja (purposive). Ketiga lapisan masyarakat petani terdiri dari: petani lapisan atas, petani lapisan menengah dan petani lapisan bawah. Setiap kelompok dipilih 5 responden sehingga total 15 responden. Pengumpulan data sekunder berasal dari Kantor Kelurahan Pandu, Kota Manado.

\section{Konsep dan Pengukuran Variabel}

1. Strategi hidup petani lapisan atas, petani lapisan menengah dan petani lapisan bawah yang merupakan cara hidup untuk memenuhi kebutuhan keluarga:

a. Sandang, yaitu berapa kali mereka membeli pakaian dalam setahun.

b. Pangan, mereka makan sehari-hari, berapa kali dalam satu hari.

c. Papan, mereka menempati rumah tinggal sekarang, sewa, beli atau bangun sendiri.

d. Pendidikan anak: menyekolahkan anak sampai di tingkat apa.

e. Kesehatan yaitu bila sakit berobat ke Puskesmas, Rumah Sakit, Klinik, dokter, atau beli di warung atau apotik. Biayanya menggunakan BPJS, atau Dana sehat, dan sebagainya. Jika tidak bagaimana penanganannya jika sakit.

f. Kebutuhan lainnya berupa kegiatan sosial ikut arisan, menabung, dan atau rukun. Koperasi, dan sebagainya.

2. Pendapatan rumahtangga petani lapisan atas (Rp/bulan), petani lapisan menengah
(Rp/bulan), dan petani lapisan bawah (Rp/bulan) adalah pendapatan yang diperoleh dari hasil bertani dan pendapatan (Rp/bulan) dari sumbersumber lain dari anggota keluarga.

3. - Pengeluaran untuk makan (Rp/bulan)

- Pola makan (pagi-siang-malam)

- Pakaian: jumlah pakaian (1 tahun)

- Tempat tinggal: milik sendiri atau milik orang lain

4. Cara mendapatkan lahan pertanian antara lain dalam bentuk membuka lahan pertanian atau menyewa pekerja tani dalam usaha pertanian.

\section{HASIL DAN PEMBAHASAN}

\section{Deskripsi Daerah Penelitian}

Jarak tempuh Kelurahan Pandu sampai di pusat kota berkisar $8 \mathrm{KM}$. Luas wilayah Kelurahan Pandu adalah sebesar 159,02 hektar yang terbagi menjadi 8 lingkungan. (Kantor Kelurahan Pandu)

Batas-batas wilayah Kelurahan Pandu sebagai berikut:

Utara : Desa Wori, Kecamatan Wori

Selatan : Kelurahan Bengkol, Kecamatan Mapanget

Timur : Kelurahan Molas, Kecamatan Bunaken

Barat : Kelurahan Bengkol, Kecamatan Mapanget

\section{Gambaran Responden}

Pada Tabel 1, umur responden petani lakilaki lapisan atas berkisar antara 40-78 tahun, sedangkan untuk umur perempuan berkisar antara 38-59 tahun. Umur responden petani lapisan menengah laki-laki antara 49-76 tahun, sedangkan untuk umur perempuan berkisar antara 46-71 tahun.Dan umur responden petani lapisan bawah laki-laki berkisar 48-58 tahun, sedangkan untuk umur perempuan berkisar antara 48-63 tahun. Umur petani laki-laki pada lapisan atas dan menengah cenderung lebih tua dibandingkan dengan usia wanitanya. Sedangkan pada lapisan bawah tidak terjadi. 
Agri-Sosioekonomi Unsrat, ISSN 1907-4298, Volume 12 Nomor 2A, Juli 2016: 91 - 106

Tabel 1. Umur Kelompok Petani Laki-Laki dan Perempuan

\begin{tabular}{lcc}
\hline \multicolumn{1}{c}{$\begin{array}{c}\text { Kelompok } \\
\text { Umur }\end{array}$} & $\begin{array}{l}\text { Jumlah } \\
\text { Laki-laki }\end{array}$ & $\begin{array}{l}\text { Jumlah } \\
\text { perempuan }\end{array}$ \\
\hline Petani lapisan atas & & \\
& 2 & 2 \\
$<51$ tahun & 1 & 1 \\
$51-59$ tahun & & 1 \\
$>59$ tahun & 2 & $\mathbf{5 1}$ \\
\hline Umur rata-rata & $\mathbf{5 7}$ & \\
\hline
\end{tabular}

Petani lapisan menengah

\begin{tabular}{lcc}
$<51$ tahun & 1 & 1 \\
$51-59$ tahun & 1 & 1 \\
& 3 & 3 \\
$>59$ tahun & 3 & $\mathbf{6 1}$ \\
\hline Umur rata-rata & $\mathbf{6 5}$ & \\
\hline
\end{tabular}

Petani lapisan bawah

$<51$ tahun $\quad 1 \quad 1$

$51-59$ tahun $\quad 4 \quad 3$

$>59$ tahun $\quad-\quad 1$

\begin{tabular}{ccc}
\hline Umur rata-rata & 54 & 54 \\
\hline Total rata-rata & 58 & 55
\end{tabular}

Sumber: Diolah dari data primer, 2016

\section{Pendidikan Petani}

Para petani menempuh pendidikan sekolah, baik Sekolah Dasar (SD), Sekolah Menengah Pertama (SMP), Sekolah Menengah Atas (SMA) dan Sarjana. Pendidikan petani lapisan atas tergolong cenderung lebih tinggi dari kedua lapisan lainnya, karena dari 5 responden kepala keluarga dan ibu rumah tangga rata-rata berlatar belakang pendidikan SMP sampai S1 (Strata 1) dan hanya 1 kepala 
rumah tangga yang berlatar belakang SD Kemudian untuk petani lapisan menengah tergolong tidak tinggi, karena dari 5 responden 1 kepala keluarga pendidikan SMA, 3 kepala keluarga pendidikan tingkat SMP, 1 tingkat SD dan untuk ibu rumah tangga 4 pendidikan SD dan 1 pendidikan SMP. Sedangkan petani lapisan bawah rendah, karena semua responden hanya sampai jenjang SD. Semakin tinggi pendidikan maka sumber daya manusia semakin tinggi dan jika tingkat pendidikan semakin rendah maka sumberdaya manusia semakin rendah.

\section{Penerimaan dari Usahatani dan di Luar} Usahatani

Petani lapisan atas yang terdiri dari: penerimaan dari bertani yaitu Rp. 2.000.000 sampai Rp. 4.666.667 terdiri dari 5 petani sehingga rata-rata penerimaan petani lapisan atas Rp. 2.541.667/bulan/petani dan untuk penghasilan di luar bekerja sebagai petani Rp.3.600.000 sampai Rp.8.000.000 terdiri dari 3 petani dan rata-rata penerimaan di luar bertani lapisan atas Rp.3.320.000/bulan/petani. Sehingga di rataratakan dari semua jumlah penerimaan petani lapisan atas sebesar Rp. 5.861.667

Tabel 2. Lama Pendidikan Petani Kepala Keluarga dan Ibu Rumah Tangga

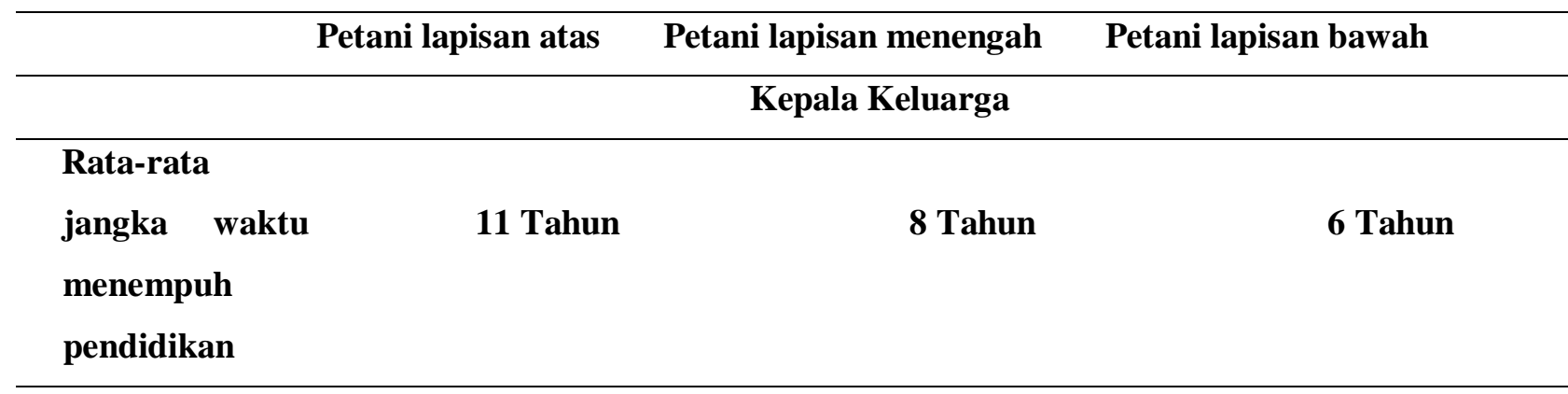

Ibu Rumah Tangga

Rata-rata
jangka waktu
menempuh
pendidikan

Sumber: Diolah dari data primer, 2016

Tabel 3. Penerimaan Petani Melalui Uahatani Dan Luar Usahatani Rata-rata Per Bulan Rata-rata penerimaan Lapisan Atas Menengah Lapan

\begin{tabular}{lccc}
\hline Usahatani (Rp/bulan) & 2.541 .667 & 941.667 & 583.333 \\
\hline $\begin{array}{l}\text { Luar Usahatani } \\
\text { (Rp/bulan) }\end{array}$ & 3.320 .000 & 1.500 .000 & 0 \\
\hline Total (Rp/bulan) & 5.861 .667 & 2.441 .667 & 583.333 \\
\hline
\end{tabular}

Sumber: Diolah dari data primer, 2016 
Petani lapisan menengah yang terdiri dari: penerimaan dari bertani yaitu Rp.500.000 sampai Rp.1.500.000 terdiri dari 5 petani sehingga rata-rata penerimaan petani lapisan menengah Rp.941.667/bulan/petani dan untuk penerimaan di luar bekerja sebagai bertani Rp. 2.000.000 sampai Rp.3.000.000 terdiri dari 3 petani dan rata-rata pendapatan di luar bertani lapisan menengah Rp. 1.500.000. Sehingga di rata-ratakan dari semua jumlah penerimaan petani lapisan menengah sebesar Rp. 2.441.667

Petani lapisan bawah yang terdiri dari: penerimaan dari bertani yaitu Rp.250.000 sampai Rp. 750.000 terdiri dari 5 petani sehingga rata-rata penerimaan petani lapisan bawah Rp.583.333 dan petani lapisan bawah tidak memiliki pekerjaan di luar bertani. Sehingga di rata-ratakan dari semua jumlah penerimaan petani lapisan bawah sebesar Rp.583.333. Sehingga bisa di simpulkan bahwa petani lapisan atas yang memiliki pendapatan terbesar di bandingkan petani lapisan lainnya dan petani lapisan bawah yang memiliki pendapatan terkecil di bandingkan petani lapisan lainnya. Bahkan pada tabel 4 menunjukan bahwa petani lapisan bawah mendapatkan pendapatan yang tidak mencukupi dalam kelangsungan hidup keluarga.

\section{Tenaga Kerja dalam Kegiatan Pertanian}

Tenaga kerja pertanian diperoleh dari dalam dan luar keluarga. Dari luar keluarga dengan cara menyewa pekerja untuk mengurus tanaman pertanian responden dan sedangkan tenaga kerja dalam keluarga denga cara bekerja sendiri tersebut dibantu oleh anggota keluarga lainnya dengan tidak memberikan upah. Penggunaan tenaga kerja di dalam dan luar keluarga disajikan pada pada Tabel 5.

Pada kelompok Petani lapisan atas, terdapat empat petani yang menggunakan tenaga kerja luar keluarga yang diupah sedangkan satu petani menggunakan tenaga kerja dalam keluarga. Petani lapisan menengah 2 menyewa pekerja sedangkan 3 petani bekerja sendiri. Dan untuk petani lapisan bawah 1 petani menyewa pekerja dan 4 petani bekerja sendiri. Kebanyakan petani lapisan bawah bekerja sendiri dalam usaha bertani karena mereka tidak memiliki cukup uang untuk membayar upah pekerja. Berbeda halnya dengan petani atas dan sebagian petani menengah dapat menyewa pekerja untuk kegiatan pertanian untuk mempermudah mereka dalam merawat kebun ataupun saat hasil panen.

\section{Kebutuhan Pangan}

Tabel 6 menunjukan pemenuhan kebutuhan pangan para petani dalam pola makan. Berdasarkan pola makan responden, maka responden untuk petani lapisan atas makan tiga kali pada waktu pagi, siang, dan malam. Untuk petani lapisan menengah 4 petani makan 3 kali pada waktu pagi, siang dan malam sedangkan 1 petani makan 2 kali pada waktu siang dan malam. Petani lapisan bawah 3 petani makan 3 kali pada waktu pagi, siang dan malam dan 2 petani makan 2 kali pada waktu siang dan malam. Bagi sebagian besar petani, 11 petani dari total 15 petani, makan 3 kali sehari. Dengan demikian semakin rendah lapisannya semakin berkurang frekuensi makannya perhari. 
Tabel 4. Pendapatan Petani perbulan

\begin{tabular}{|c|c|c|c|}
\hline & $\begin{array}{l}\text { Lapisan atas } \\
\quad(\mathrm{Rp})\end{array}$ & $\begin{array}{l}\text { Lapisan } \\
\text { menengah } \\
\quad(\mathrm{Rp})\end{array}$ & $\begin{array}{l}\text { Lapisan bawah } \\
\text { (Rp) }\end{array}$ \\
\hline $\begin{array}{l}\text { Rata-rata Penerimaan per bulan } \\
\text { - Pertanian } \\
\text { - Non Pertanian }\end{array}$ & $\begin{array}{l}2.541 .667 \\
3.320 .000\end{array}$ & $\begin{array}{c}941.667 \\
1.500 .000\end{array}$ & $\begin{array}{c}583.333 \\
0\end{array}$ \\
\hline $\begin{array}{c}\text { Total Rata-rata Penerimaan per } \\
\text { bulan }\end{array}$ & 5.861 .667 & 2.441.667 & 583.333 \\
\hline Rata-rata Pengeluaran per bulan & & & \\
\hline $\begin{array}{l}\text {-Makanan } \\
\text {-Non-makanan }\end{array}$ & $\begin{array}{l}2.400 .000 \\
1.064 .000\end{array}$ & $\begin{array}{c}1.800 .000 \\
842.700\end{array}$ & $\begin{array}{l}1.680 .000 \\
754.000\end{array}$ \\
\hline $\begin{array}{c}\text { Total Rata-rata Pengeluaran } \\
\text { per bulan }\end{array}$ & 1.732.000 & 1.321.350 & 1.217.000 \\
\hline $\begin{array}{c}\text { Rata-rata Pendapatan } \\
\text { perbulan }\end{array}$ & 4.259.666 & 1.120.316 & -633.666 \\
\hline
\end{tabular}

Tabel 5. Penyewaan Tenaga Kerja dalam Keluarga dan Tenaga Kerja Luar Keluarga

Menyewa Tenaga Kerja Jumlah Responden

\section{Petani lapisan atas}

Tenaga Kerja Luar Keluarga 1

Tenaga Kerja Dalam Keluarga 4

Sub-Jumlah 5

Petani lapisan menengah

Tenaga Kerja Luar Keluarga 3

Tenaga Kerja Dalam Keluarga 2

Sub-Jumlah $\quad 5$

Petani lapisan bawah

Tenaga Kerja Luar Keluarga 4

Tenaga Kerja Dalam Keluarga 1

Sub-Jumlah $\quad 5$

$\begin{array}{ll}\text { Jumlah } & 15\end{array}$

Sumber: Diolah dari data primer, 2016 
Agri-Sosioekonomi Unsrat, ISSN 1907-4298, Volume 12 Nomor 2A, Juli 2016: 91 - 106

\section{Tabel 6. Pola Makan Keluarga Petani}

Pola Makan Jumlah

\section{Petani lapisan atas}

Pagi-siang-malam

Pagi-sore

Siang-malam

Sub-Jumlah

\section{Petani lapisan menengah}

Pagi-siang-malam

Pagi-sore

Siang-malam

\section{Petani lapisan bawah}

Pagi-siang-malam

Pagi-sore

Siang-malam

Sub-Jumlah 


\section{Kebutuhan Sandang}

Untuk memenuhi kebutuhan sandang responden membeli pakaian dalam setahun ada satu kali, dua kali, dan lebih dari 3 kali. Pada Tabel 7 menunjukkan pembelian pakaian bagi para petani dan keluarganya dalam satu tahun sepanjang tahun 2015.

Petani lapisan atas ada 2 keluarga petani yang membeli pakaian lebih dari 3 kali dalam setahun, 2 keluarga petani dua kali dalam setahun dan ada 1 keluarga petani yang membeli 1 tahun sekali untuk keperluan Hari Raya Kristen atau Hari Raya Islam. Petani lapisan menengah ada 2 keluarga petani yang membeli 2 kali dalam setahun dan 3 keluarga petani yang membeli 1 tahun sekali. Petani lapisan bawah 1 keluarga petani yang membeli lebih dari 3 kali dalam setahun, 2 keluarga petani yang membeli 2 kali dalam setahun dan 2 keluarga petani membeli 1 tahun sekali. Pakaian yang di belikan untuk keperluan pakaian sekolah anak-anak atau pakaian untuk natal dan tahun baru sedangkan orangtua membeli pakaian hanya setahun sekali. Pada lapisan atas dan menengah terdapat kecenderungan semakin tinggi lapisan semakin banyak frekuensi pembelian baju. Kebanyakan petani membeli pakaian pada Hari Raya seperti Hari Natal, Tahun Baru ataupun Idul Fitri pada tahun 2015.

\section{Kebutuhan Papan}

Kebutuhan akan papan atau tempat tinggal merupakan salah satu kebutuhan dasar yang dapat dikatakan sejalan dengan kebutuhan pangan, karena setiap orang selain butuh makan juga butuh tempat tinggal, untuk berteduh dari teriknya panas dan hujan, tempat untuk beristirahat dan juga sebagai tempat berkumpulnya keluarga. Adapun status rumah dan tanah milik sendiri namun sebagian petani status rumah dan tanah adalah milik pemerintah (tanah negara).

Cara mendapatkan rumah dari pemerintah (tanah negara) adalah masyarakat yang kurang mampu, sehingga petani tersebut mendapatkan rumah dan mendapatkan lahan tanah untuk tinggal. Ada juga beberapa petani yang memiliki kendaraan motor kemudian satu petani memiliki mobil pribadi dan rata-rata dari petani mempunyai tabungan di bank.

\section{Keadaan Kesehatan Dan Pendidikan Anak- Anak}

Kesehatan petani pada umumnya baik karena hampir tidak pernah mengalami sakit yang parah. Kesehatan terganggu, hanya sakit yang ringan berupa flu, panas, dan batuk. Jika sakit responden rata-rata mempunyai kartu Jamkesmas maupun BPJS sehingga banyak yang memilih ke Puskesmas atau pun dokter. Kecuali sakit yang parah maka responden memilih untuk datang ke rumah sakit. Pendidikan anak-anak sebagian besar yang sudah tidak bersekolah sampai pendidikan SMA dan ada juga yang masih bersekolah sampai saat ini.

\section{Strategi Hidup Masyarakat Petani}

Responden sebagian besar pada awalnya adalah petani pemilik penggarap yaitu petani lapisan atas dan petani lapisan menengah. Dari hasil yang di dapatkan di simpan sebagian untuk membeli hewan sapi kemudian di kembang-biakan. Setelah sapi sudah mulai banyak di jual, sehingga dari pendapatan yang di dapatkan dari hasil menjual sapi dan hasil bertani di belikan tanah untuk membuka lahan pertanian. Jadi pada petani lapisan atas dan menengah terdapat gejala penerapan strategi akumulasi dan tidak ditemukan strategi konsolidasi.

Ada juga responden yang mendapatkan tanah dari warisan orang tua, sehingga dengan warisan tersebut di buatlah usaha untuk membuka lahan pertanian dan sebagian petani meminjam lahan dari tuan tanah, dengan syarat hasil dari bertani tersebut di jual ke tuan tanah. Mereka membuka lahan pertanian dan memperoleh bantuan dari pemerintah, antara lain, berupa bibit, pupuk, dan pestisida. Ada juga dari hasil tabungan keluarga untuk membeli tanah sehingga bisa membuka lahan pertanian.

Berdasarkan hasil wawancara pada petani ditemukan bahwa setiap lapisan melaksanakan strategi hidup/nafkah yang berbeda. 
Agri-Sosioekonomi Unsrat, ISSN 1907-4298, Volume 12 Nomor 2A, Juli 2016: 91 - 106

\section{Tabel 7. Pembelian Pakaian Para Petani dan Keluarganya dalam Setahun}

Pembelian Pakaian dalam (tahun) Jumlah Responden

Petani lapisan atas

> Tiga kali

2

Dua Kali

2

$<$ Satu Kali

1

Sub-Jumlah

Petani lapisan menengah

$>$ Tiga kali

Dua Kali

2

$<$ Satu Kali

3

Sub-Jumlah

5

Petani lapisan bawah

>Tiga kali

1

Dua Kali

2

$<$ Satu Kali

2

Sub-Jumlah

Jumlah

15

Sumber :Diolah dari data primer, 2016 
Tabel 8. Status Rumah Tinggal dan Tanah Milik

\begin{tabular}{lc}
\hline Status Rumah dan Tanah & Jumlah Responden \\
\hline Petani lapisan atas & 5 \\
Rumah (Milik Sendiri) & 5 \\
Pekarangan (Milik Sendiri) & \\
Petani lapisan menengah & 5 \\
Rumah (Milik Sendiri) & 5 \\
Pekarangan (Milik Sendiri) & \\
& \\
Petani lapisan bawah & 5 \\
Rumah (Milik Sendiri) & 4 \\
Pekarangan (Milik Sendiri) & 15 \\
\hline Jumlah Responden & \\
\hline
\end{tabular}

Sumber: Diolah dari data primer, 2016

\section{Petani Lapisan Atas}

Dari 5 responden petani lapisan atas, 2 responden yang mendapatkan tanah dari warisan orang tua. Pengelolaan lahan warisan yang tepat sehingga dapat diperluas menjadi lahan pertanian yang ditanami berbagai macam tanaman, baik tanaman kelapa, tanaman jagung, tanaman pisang dan tanaman yang lainnya. Petani pada lapisan ini sebaian besar cenderung membeli tanah lebih dari satu kali. Selain itu, sebagian dari petani lapisan ini dapat menyewa petani penggarap lainnya baik menjaga kebun ataupun membantu memanen hasil dari pertanian. Petani lapisan atas ini juga menyimpan hasil dari pertanian ini di bank, sehingga pada saat ada yang akan menjual tanah mereka mengambil uang di bank untuk membeli tanah tersebut. Sebagian juga dari strategi petani lapisan ini membeli sapi, agar di saat di perlukan membeli tanah ataupun membeli usaha untuk bertani sapi yang di pelihara bisa di jual dan ada juga yang di temukan petani yang membuka usaha lain seperti menjual minuman paket untuk menambah kebutuhan hidup petani. Karena petani lapisan ini, uang yang didapatkan cenderung di investasikan untuk membeli tanah yang lain dari hasil tabungan di bank ataupun hasil usaha selain bertani.

\section{Petani Lapisan Menengah}

Pada umumnya petani lapisan menengah adalah petani penggarap yang hasil dari bertani di simpan sendiri untuk kebutuhan keluarga, membeli keperluan untuk bertani ataupun di belikan sapi untuk di kembangbiakan. Setelah dari hasil bertani dan sapi yang di kembang biakan di jual untuk membeli kebutuhan bertani bahkan mereka bisa membeli tanah dari hasil tersebut. Petani lapisan ini tidak seperti petani lapisan atas yang 
menginventasikan hasil dari bertani dengan membeli tanah, tetapi untuk petani lapisan ini hanya dua petani yang membeli tanah sebanyak satu kali saja untuk membuka lahan pertanian dan dari hasil tersebut hanya untuk melangsungkan kebutuhan hidup keluarga.

\section{Petani Lapisan Bawah}

Untuk petani lapisan bawah, cenderung menerapakn strategi bertahan hidup. Mereka semua merupakan petani penggarap di tanah atau lahan pertanian orang lain. Petani lapisan ini mereka hanya berpikir untuk kebutuhan keluarga dan modal untuk membeli kebutuhan bertani. Jadi untuk petani lapisan ini, mereka tidak pernah berpikir untuk membeli lahan pertanian, karena menurut mereka dari hasil yang mereka dapatkan tidak cukup untuk membeli tanah bahkan untuk memenuhi kebutuhan keluargapun tidak cukup. Untuk mencukupinya mereka meminjam uang tetangga tapi untuk kebutuhan pertanian mereka meminjam kepada koprasi. Kegiatan pertanian merupakan satu-satunya sumber pendapatan yang dapat terus mereka lakukan untuk memenuhi kebutuhan hidup keluarga, baik makan, baju yang di gunakan ataupun biaya anak sekolah setiap hari.

\section{KESIMPULAN DAN SARAN}

\section{Kesimpulan}

Hasil penelitian menunjukan bahwa petani lapisan atas dan petani lapisan menengah cenderung menerapkan strategi akumulasi sedangkan strategi konsolidasi tidak ditemukan. Mereka memiliki pendapatan yang melebihi kebutuhan untuk bertani dan dari hasil tersebut mereka bisa membelikan Sapi, tanah atau aset lainnya. Petani lapisan bawah menerapkan starategi bertahan hidup. Setengah dari pendapatan mereka yang lebih memilih setengah pendapatan untuk kebutuhan keseharian keluarga dan setengahnya lagi untuk bertani. Keterbatasan pendapatan membuat petani tidak dapat menabung bahkan mereka harus meminjam uang untuk menambah pendapatan keluarga baik makan ataupun membeli perlengkapan sekolah untuk anakanak.

\section{Saran}

Berdasarakan penemuan pada penelitian ini, bahwa untuk meningkatkan standar hidup keluarga petani diperlukan kualitas sumber daya yang tinggi dan modal awal berupa pemilihan lahan pertanian untuk itu kebijakan affirmative oleh pemerintah perlu dilakukan pada petani lapisan bawah apakah mereka dapat melakukan mobilitas sosial vertikal, untuk keluar dari kemiskinan bahkan untuk menjadi petani lapisan menengah atau lapisan atas.

\section{DAFTAR PUSTAKA}

Jannah, W., dan Kadarisman, 2015. Strategi Bertahan Hidup Buruh Tani Sawit di Kelurahan pasir Sialang Kecamatan Bangkinang Kabupaten Kampar.Jurnal Online Mahasiswa (JOM) Bidang Ilmu Sosial dan Ilmu Politik.

Juwanita. 2004. Tesis. Perempuan dan Kemiskinan. Makassar: Pascasarjana Universitas Hasanudin.

Kawalo, A.Y., Ngangi, C.R. and Loho, A.E., 2016. Kajian Bertahan Hidup Pemulung Di Tempat Pembuangan Akhir Sampah Kelurahan Sumompo Kecamatan Tuminting, Manado. AGRI-SOSIOEKONOMI, 12 (1), pp. 47-54.

Khairani, N. 2010. Dampak Industrialisasi Terhadap Kehidupan Sosial Ekonomi Masyarakat Desa (Studi Kasus: Dampak PT. Inalum Terhadap Warga Desa Lalang Kecamatan Medang Deras).

Lubis, M. 1999. Strategi Hidup Rumah Tangga Petani Miskin Pada Saat Krisis Moneter (Studi Kasus: Rumah Tangga Miskin di Desa Wargaluyu, KecamatanTanjung Kerta, Kabupaten Sumedang, Propinsi Jawa Barat). Bogor: Fakultas Pertanian, Institut Pertanian Bogor. 
Lutfia, Chaula.2015 "Pola Pembagian Hak Dan Kewajiban Keluarga Muslim: Studi Kasus Pencari Nafkah Wanita Di Dusun Makam Dawa." Phd Diss., Uin Sunan Kalijaga.

Mamik. Suvival Mechanism Victim Household Of Lumpur Lapindoin Siduarjo-Jawa Timur.

Mardikanto, 2005. Metode dan Teknik Penyuluhan Pertanian. Surakarta : Prima Theresia Pressindo.

Mardikantoro, H. B. 2013. Bahasa Jawa Sebagai Pengungkap Kearifan Lokal Masyarakat Samin Di Kabupaten Blora. Komunitas: International Journal of Indonesian Society And Culture.

Moertopo, A. 1974. Strategi politik nasional. Jajasan Proklamasi, Centre for Strategic and International Studies

Moser, C.O., 1998. The Asset Vulnerability Framework: Reassessing Urban Poverty Reduction Strategies. World Development, 26 (1), pp.1-19.

Mosher. 1970. Getting Agriculture Moving How Moder Farming Can Provide ABetter Life. Pyramid Book. New York.

Muhammad. 2014. Strategi Penghidupan Rumah Tangga Miskin Perdesaan (Kasus Di Tiga Desa Kabupaten Kulon Progo Daerah Istimewa Yogyakarta)

Nugroho, S. G. Setiawan. A., dan Harianto, S.P. (1991).Coupled Ecosystem SilvoFishery.Bentuk Pengelolaan Hutan Mangrove-Tambak Yang Saling Mendukung dan Melindungi dalam Prosiding Seminar IV Ekosistem Mangrove.Panitia Nasioanal Program MAB Indonesia-LIPI. Jakarta

Patiwiri, A.W, 2007. Kemitraan dalam Upaya Peningkatan Kuantitas dan Kualitas Produksi Padi "Majalah Pangan". No49/XVI/Juli/2007.

Ritzer, 2004. Sosiologi Ilmu Berparadigma Ganda. Jakarta: PT. Raja Grafindo Persada.
Sajogyo. 1985. Sruktur Sosial dan Organisasi: Pengantar Kuliah Program Pascasarjana. Program Studi Sosiologi Pedesaan. Institut Pertanian Bogor.

Samsudin, S. 1982. Dasar-Dasar Penyuluhan dan Modernisasi Pertanian. Bandung: Angkasa Offset.

Scott, J. 1990. Perlawanan Kaum Tani. LP3ES. Jakarta.

Scott, J. 1985. Moral Ekonomi Petani. LP3ES, Jakarta.

Sugihardjo, Lestari dan Wibowo. 2012. Strategi Bertahan dan Strategi Adaptasi Petani Samin Terhadap Dunia Luar (Petani Samin Di Kaki Pegunungan Kendeng Di Sukolilo Kabupaten Pati)

Suharni Z. 2007. Studi Sosial ekonomi dan Persepsi Masyarakat terhadap Rencana Pembangunan Hutan Tanaman Pola Kemitraan (HTPK) PT Arara Abadi Provinsi Riau. Departemen Manajemen Hutan, Fakultas Kehutanan, Institut Pertanian Bogor.

Sumar, T. 1991. Sistem Intervensi Kesejahteraan Sosial.Yogyakarta:PT. Hanindita.

Wahyudi, A. S. 1996. Manajemen Strategik: Pengantar Proses Berpikir Strategik. Binarupa Aksara. Klaten.

Warsani, H. 2013. Kajian Pemanfaatan Lahan Sawah Di Kecamatan Kuantan Tengah Kabupaten Kuantan Singingi (Doctoral dissertation, Universitas Pendidikan Indonesia).

White, T. J., BRUNS, T., LEE, S. J. W. T., DAN TAYLOR, J. W. 1990. Amplification and Direct Sequencing Of Fungal Ribosomal RNA Genes For Phylogenetics.

Xing Ying 2013 A Study of the Stability of Contemporary Rural Chinese Society 